\title{
Blameworthy Environmental Beliefs
}

\begin{abstract}
Daniel C. Fouke*
Thomas Hill, Jr. has famously argued that what really bothers us about environmental degradation is best discovered by asking "What kind of person would do such a thing?" Beliefs, some of which are blameworthy, are among the things that define what kind of person one is. What we care about is reflected in whether one's epistemic practices align with one's core moral convictions and common standards of decency. Our moral sensitivities are reflected in what we attend to and reflect upon. What we do not notice can be a result of culpable indifference or self-deception. Environmental beliefs formed with negligent disregard for the risks they create for others are reflections of a vicious moral character. Beliefs of citizens have consequences. They determine what politicians will respond to and what policies they will introduce. Ideological commitments have been shown to influence what one takes to be the facts about risks. When the ethical dimensions of environmental beliefs and ignorance are unchallenged, society drifts morally. Emphasizing the relationship between commonly shared moral convictions (more basic than ideological commitments) and risky environmental beliefs and actions has more potential to create environmental awareness than the current focus on environmental science and the economic benefits of better environmental policies.
\end{abstract}

\section{INTRODUCTION}

Thomas Hill, Jr. has argued that asking "What kind of person would do such a thing?" best captures our moral reaction to environmental degradation. ${ }^{1}$ That question leads to a whole series of further questions. One of the reasons persons act in the ways they do is the particular beliefs they hold. So, among the things we must further ask are (1) "What kind of person would hold and be motivated by the beliefs that lead him or her to do the kinds of things he or she does?" Or, in cases where the actions are based on ignorance, we might ask (2) "What kind of person would be ignorant of the facts that might dissuade him or her from doing the kinds of things he or she does?" Further, much of the harm that is occurring to the environment is based on inaction. Citizens and politicians threaten the welfare of humanity because they do nothing to halt systematic degradation of the environment. This is clearly the case with regard to climate change. To effectively address it would have required radical policies introduced decades ago; yet even now the United

* Department of Philosophy, University of Dayton, 300 College Park, Dayton, OH 45469-1546; email: Daniel.fouke@notes.udayton.edu. Fouke's primary research has been in early modern philosophy. He is the author of Philosophy and Theology in a Burlesque Mode: John Toland and the Way of Paradox (New York: Prometheus Books, 2005) and The Enthusiastical Concerns of Dr. Henry Moore: Religious Meaning and the Psychology of Delusion (Leiden: E. J. Brill, 1997). More recently he has been working in political and environmental philosophy and has published "Democratic Deliberation and Moral Awareness," Journal of Public Deliberation 5 (2009): art. 10 (http://services.bepress.com/ jpd/vol5/iss1/art10) and "Humans and the Soil," Environmental Ethics 33 (2011): 147-61.

${ }^{1}$ Thomas Hill, Jr., "Ideals of Human Excellence and Preserving Natural Environments," in Ronald Sandler and Philip Cafaro, eds., Environmental Virtue Ethics (New York: Rowman and Littlefield, 2005), pp. 47, 50. 
States is nowhere near agreement on a course of action. One who examines the issues closely would conclude that we are in the midst of an environmental crisis. Not only the American Academy of Sciences, but academies of science in South Africa, the United Kingdom, Brazil, Canada, Italy, India, China, Japan, France, Russia, Mexico, and Germany have issued statements urging immediate action on climate change. But climate change is far from the only environmental problem we face. To mention only a few others, the increasingly rapid decline of pollinators places our food supply at risk; our waters are so polluted that we are regularly warned to limit the number of fish we eat; and every person on the planet carries a chemical body burden, so that one of the most intimate, healthful, and loving human acts - breastfeeding - forces new mothers to weigh the risk of exposing their infants to the toxins that contaminate mother's milk. ${ }^{2}$ So we must also ask, (3) "What kind of persons would hold beliefs that produce resistance to action under circumstances so dire and threatening?" (4) "What kind of persons would be ignorant of such important facts that might motivate him or her to act?" While it is obvious that excusing conditions can exist, I argue that in seeking to answer these questions we will find that some cases of environmental beliefs or ignorance are vicious or culpable.

\section{CULPABLE IGNORANCE, RECKLESSNESS, AND NEGLIGENCE}

People whose false beliefs or ignorance lead them to action or inaction do not intentionally harm others. But our language, and our legal system, contains adjectives for blameworthy, but unintentional, wrongdoing: the synonyms carelessness, recklessness, ${ }^{3}$ and negligence. Negligence and culpable ignorance occur when agents do not pay attention to, or are ignorant of, the risks they impose upon others. How can one be morally blameworthy for violating a norm unknowingly? Culpability, in such instances, must rest upon the claim that one ought to be aware-one ought to know. Discussions of mens rea ("guilty mind") by legal scholars shed some light on these issues.

To be guilty of most crimes, a defendant must have committed the criminal act - the actus reus - in a certain mental state - the mens rea. For example, to be criminally liable for robbery, the action must be accompanied by the intention to permanently deprive the owner of his property. But Kimberly Ferzan brings up an example to show the complexity of determining what constitutes a "guilty mind" in cases of recklessness and negligence. She asks us to imagine a man rushing late to work who sees a yellow light in the intersection ahead, which he expects to turn red just as he approaches the intersection, but he decides to drive through the intersection anyway. As he does, a pedestrian walks in front of his car and is struck dead. This act makes him guilty of criminal homicide, but the degree and nature of

\footnotetext{
${ }^{2}$ See Florence Williams, “Toxic Breast Milk,” New York Times Magazine, 5 January 2008, http:// www.nytimes.com/2005/01/09/magazine/09TOXIC.html.

${ }^{3}$ Recklessness is derived from the now-archaic verb to reck, meaning "to care or have concern for."
} 
his guilt - "whether it is murder, manslaughter, or negligent homicide" - depend on his mental state at the time. He is not guilty of murder because he did not intend to kill the pedestrian. Nor, according to the modern penal code, was he reckless because he did not consciously disregard a "substantial and unjustifiable risk" that he might kill someone. He did not think to himself, "Well, I might kill someone, but I am going to do it anyway, because I do not want to arrive late to work." Some do consciously engage in risky behavior. A woman driving to a bar to get drunk, while fully aware of the dangers she would pose on her drive home, would be guilty of reckless behavior. Ferzan calls this kind of behavior "pure recklessness."4

Was the man rushing to work negligent? That would require that he be "merely unreasonably unaware of the substantial and unjustifiable risk" he took. What distinguishes recklessness from negligence is awareness and foresight. A reckless agent is aware of the risk, but takes it, while a negligent agent is unaware of a risk that he or she ought to have been aware of and is guilty of culpable ignorance. When it is impossible to know the risks, ignorance is not culpable, but an excuse. Ferzan argues that he or she was more than negligent. An example of negligence would be, for example, failing to even be aware that one was running a red light and risking the death of a pedestrian because one is busy adjusting the radio. This person did consciously run the red light and knew that doing so was risky behavior. Ferzan's complaint against the modern penal code is that it does not recognize the guilt of this sort of behavior and defines "pure recklessness" as the minimal level of culpability. Ferzan calls for criminalization of what she calls "opaquely reckless" actors - people who consciously engage in risky behavior while failing to think through and weigh the risks as they ought to: “. . . by their choices to engage in dangerous actions, these people have shown themselves to be culpable, and thus deserving of punishment ... since they know the dangerousness of their acts and therefore can decide whether to commit those acts." 5 But moving from criminal to moral culpability, can we say of American citizens and politicians that they consciously engage in environmentally risky behavior or consciously support policies that pose risks to others? Often this is not an easy question to answer.

If one does not believe that an environmental threat is occurring, can one reasonably be blamed for supporting risky policies or not supporting policies designed to lower the risks? The most serious environmental risks are systematically imposed by political and economic systems. Whether one takes the problem seriously enough to act depends partly on one's confidence in the responsiveness of government. In general, Americans have very little confidence in their governing institutions, and it must be admitted that it is for good reason. But the beliefs of citizens and policy makers are one of the obstacles to adopting policies that mitigate environmental risks. While one of the most important obligations of citizenship is to know basic

\footnotetext{
${ }^{4}$ Kimberly Ferzan, "Criminal Law: Opaque Recklessness," Journal of Criminal Law and Criminology 91 (2001): 597-98.

${ }^{5}$ Ibid., pp. 599, 601.
} 
facts relevant to decisions about what policies to support, this responsibility is not easily met because of the many social forces that influence the formation of belief.

For example, suppose that Joe was raised in a family that frequently rants about environmental "wackos," their socialist agenda and desire to seize or control the property of freedom-loving citizens, the "junk" science they use to support their claims, and the exaggeration of environmental problems by the media. Suppose Joe's parents never turn the dial from a particular radio station that, without exception, espouses similar views, and suppose that Joe regularly visits websites debunking climate change and the seriousness of environmental degradation. Joe is surrounded by "information" that assures him that the agenda of environmentalists is not based on trustworthy science, but base, self-serving, and unpatriotic motives. Environmental disinformation is widely disseminated and Peter Jacques has extensively documented the vast sums of money and effort spent on deluding people through such things corporately funded conservative think tanks. ${ }^{6}$ Indeed, some studies have shown that among those who primarily get their information from Fox News, the greater attention they pay to the news the more likely they are to have false beliefs on some important issues. ${ }^{7}$

Joe's parents, his favorite television and radio programs, and a whole network of sites on the web reinforce his views daily. Joe trusts only sources that confirm his views and rarely bothers to expose himself to others. Why should it be otherwise when so many in his trusted social circle defame these other sources of information? When he does hear other points of view, he immediately dismisses their credibility. Joe has, in some sense, been brainwashed and, through selective attention, participates in continuing to brainwash himself. Under conditions such as these, can it really be said that his beliefs are morally blameworthy? Could he really believe otherwise?

Or suppose Pam was raised in a family that fatalistically adopts the attitude that there is no point in worrying or involving oneself in active citizenship because the deck is stacked against the little people. Pam does not inform herself about policy, electoral politics, or ecologically important facts because there is no point in worrying about things that can't be changed. Joe has mistaken beliefs, but Pam is convinced that she is powerless and, because of this belief, she is simply ignorant of the relevant facts and absent of concern. Excusing conditions seem to absolve both Joe and Pam of blame for their beliefs. Yet some of us wonder whether such destructive beliefs and attitudes might indeed be culpable.

Steven Sverdlik surveys the differing methods by which philosophers have tried to analyze the foundations of the moral discomfort some of us feel when confronted with such cases. On one view, which he traces to Aristotle, one is culpably mistaken

\footnotetext{
${ }^{6}$ Peter Jacques, Environmental Skepticism (Surrey, England: Ashgate, 2009).

${ }^{7}$ Steven Kull, Clay Ramsay, and Evan Lewis, "Misperceptions, the Media, and the Iraq War," Political Science Quarterly 118 (Winter 2003/2004): 569-98; Woods Institute Report, "Frequent Viewers of Fox News are Less Likely to Accept Scientists' Views of Global Warming," December 2010 (http:// woods.stanford.edu/docs/surveys/Global-Warming-Fox-News.pdf)
} 
only if, at some earlier time one intentionally or negligently brought about a sequence of events that led to adopting a mistaken belief on which one later acted or which caused one to omit acting when one should have. ${ }^{8}$ For example, suppose a medical doctor and an electrician are on a subway when a woman succumbs to a serious ailment that requires immediate attention. Suppose this ailment is an instance of an epidemic that has been sweeping through the city. Suppose that the doctor, let us call him "Dr. Dinwiddy," would have known how to treat her on the spot if he had kept up with his professional reading, but he did not take the time to read the medical journals containing this vital information. Neither Dr. Dinwiddy nor the electrician has the knowledge of how to treat her. But Dr. Dinwiddy, and not the electrician, would be culpable. Dinwiddy has the necessary expertise and training and is obligated by his professional role to know such things. Dr. Dinwiddy is culpable because he ought to have known, but acted negligently at some earlier time, knowingly taking the risk of being unequipped to help victims of the epidemic.

Michael Zimmerman and Holly Smith are exponents of this "Aristotelian view," according to which to be culpable for an ignorant act, one must be culpable for the ignorance that produced that act. Zimmerman claims (without explanation) that "one is never in control of whether one is ignorant." So, if the ignorance is culpable, it must be derived from its relationship with something else that is directly culpable. That culpable act must involve the agent's belief that he or she is doing something immoral. Since the ignorance is only a consequence of the culpable act, it is not culpable in itself or "substantially" culpable. Zimmerman claims that turpitude depends upon a "cognitive connection" between the agent and some shameful act, by which he seems to mean that the agent must believe that the action might bring about some harm or substantial risk. ${ }^{9}$ So to be culpable for being unable to rescue the passenger on the subway, Dr. Dinwiddy must have considered the risks of not reading reports on how to treat victims of the epidemic, but then thought something like, "Instead, I'm going to play with my model trains." Furthermore, Dr. Dinwiddy must believe that this action is morally wrong. Zimmerman would say that there is no culpability in Joe's active opposition to environmental reform or in Pam's failure to take action to address environmental problems, however urgent they are, because their beliefs were not preceded by conscious decisions to create risks by adopting certain beliefs or foregoing the pursuit of knowledge.

Holly Smith claims ignorance is culpable when it is a result of an act of "benighting" - "an initial act, in which the agent fails to improve (or positively impairs) his cognitive position" which produces a "subsequent act in which he does wrong because of his resulting ignorance." The benighting act produces a kind of epistemic disability. In cases such as that of Dr. Dinwiddy, the initial act can be an omission. To be benighting, the act of omission "must be objectively wrong: the agent could have acquired the requisite information, ought to have done so, but

\footnotetext{
${ }^{8}$ Steven Sverdlik, "Pure Negligence," American Philosophical Quarterly 30 (1993): 139-40.

${ }^{9}$ Michael Zimmerman, “Moral Responsibility and Ignorance," Ethics 107 (1997): 418-20.
} 
failed to fulfill this obligation." The agent might be doing the best he or she can, given the disabilities he or she has brought upon him or herself. But the agent will be culpable for the prior benighting and will be responsible for the subsequent action or inaction it causes. One is to blame for the subsequent action only insofar as one knowingly risked it in the prior benighting act. ${ }^{10}$

Sverdlik criticizes Smith because he thinks that one can be guilty of negligence without a prior benighting act, even when one has not deliberately failed to acquire knowledge relevant to a risk. Instead of locating the blameworthiness of negligence in a prior conscious act of benighting, Sverdlik identifies the source of culpability in the failure to consciously intervene, through "moral reflection," in the processes of thought that usually go on automatically and that, when they do, lead to the unwitting violation of a norm. One ought to reflect on the relationship between one's actions and the moral principles that one already accepts. He calls acts resulting from the failure to do so "pure negligence." 11

For example, consider the doctor. Suppose that on the night before that fatal event, when he had set aside time to read his medical journals, he decided first to play with his children. Suppose before he knew it, the time was gone. He was tired and faced a long day tomorrow, so he went to bed, forgetting about the journals. Upon Smith's view, Dr. Dinwiddy would not be guilty of negligence because he did not consciously decide to neglect his professional reading. But it would seem that he is culpable. He did not exercise the diligence that he himself recognized as a duty, under circumstances that made it urgent he do so-the spreading epidemic. Joe did not think to himself, "I ought to investigate the scientific basis for concerns about the loss of biodiversity and climate change so that I know that I am on the right track in my views and the policies I am supporting, but I won't." It never occurred to him to investigate because he is convinced that the science is mere propaganda. But in matters so important and when the risks are so great, he ought to have been especially diligent in checking the credibility of his sources. Blissfully ignorant Pam ought to have investigated whether it is true that citizens cannot make a difference, whether there are effective strategies of political action, and whether there are issues of such great urgency that one has a duty to act. Her fatalism might have yielded to knowledge of how political activity led to the freeing of the enslaved, women's suffrage, or the winning of civil rights.

In Sverdlik's cases of "pure negligence" the agent is violating a norm through risky behavior and is not aware of it, but ought to have been. He emphasizes the degree to which the mental states that lead to pure negligence are not discrete or deliberate actions but cognitive processes that occur automatically. We do sometimes deliberately develop morally important habits to avoid imposing risks, such as checking our rear-view mirrors before changing lanes. These habits do away with some of the need to consciously intervene in cognitive processes. But often

\footnotetext{
${ }^{10}$ Holly Smith, “Culpable Ignorance,” Philosophical Review 92 (1983): 547, 551, 552, 565-66.

${ }^{11}$ Steven Sverdlik, "Pure Negligence," American Philosophical Quarterly 30 (1993): 140-42.
} 
habits alone will not guide us aright. In some instances we can and ought to take deliberate steps to inform ourselves of what is needed to meet our moral obligations. The moral principles we hold give us reasons to do the things we do, and they include investigating whether these principles apply to our behavior. Morally conscientious agents are committed to aligning their actions with their moral beliefs and investigating whether they are likely to be violating them. ${ }^{12}$ This view is surely right, as it is simply what it means to act responsibly.

James Montmarquet similarly characterizes culpable ignorance as the forming of beliefs with an intellectually irresponsible attitude. ${ }^{13}$ Moreover, he argues against a strict separation between intellectual and moral irresponsibility:

[A]n important part of Hitler's intellectual irresponsibility is that he remains confident of the truth of what he believes (and supremely indifferent to the need to rethink or reinvestigate these beliefs), even as he is aware (or certainly should have been aware) of what a moral catastrophe would ensue if these beliefs were wrong. An unwillingness to reconsider one's beliefs, in any such circumstance, is morally irresponsible, to be sure-but it is also the height of intellectual irresponsibility. ${ }^{14}$

Victor Tadros makes a similar point while discussing a court case in which someone shot at a target in a forest without checking whether someone was walking through it. The defendant pleaded not guilty, on the basis that he did not realize others might be walking there. Tadros argues that his action was culpable and his character vicious because he failed to attend to the moral significance of reasons for not acting as he did. Moral evaluations of agents, he claims, depend both upon whether the reasons to perform the action were really justified and whether the agent had the appropriate attitude toward the reasons against. ${ }^{15}$ This must be correct. Sensitivity to the risks one imposes on others is a core moral responsibility, and insensitivity is a vicious and blameworthy moral attitude.

\section{SELF-DECEPTION}

But it is not always clear whether persons could know the risks they are posing. Sometimes we believe what we are told on good authority, and it turns out to be wrong. Sometimes we seem to have a choice between conflicting authorities. Sometimes we might suspend critical judgment out of an ideological commitment. And sometimes we sincerely hold beliefs based on a desire to believe what is comforting and will let us off the hook, rather than to face unpleasant facts. Of course, one way of controlling belief is to engage in an open-minded inquiry. But there are other, less praiseworthy ways of controlling one's beliefs based on vicious epistemic attitudes. Let me illustrate.

\footnotetext{
${ }^{12}$ Sverdlik, "Pure Negligence," 141-42.

${ }^{13}$ James Montmarquet, "Culpable Ignorance and Excuses, Philosophical Studies 80 (1995): 42, 45.

${ }^{14}$ Ibid., p. 47.

15 Victor Tadros, Criminal Responsibility (Oxford: Oxford University Press, 2005), pp. 90, 227.
} 
A few years ago, while discussing climate change with my class, several students mentioned that Ed had convinced them that it was all a fuss about nothing based on bad science. I asked Ed to share his arguments, but he was unwilling. I asked Ed to share with me privately, by email, the arguments and facts that he had used to persuade his fellow students. Not surprisingly, it was taken from websites devoted to debunking concerns about global warming. I wrote him a long memo addressing, as best I could, the claims of these "climate skeptics," sent copies of reports summarizing the scientific basis for climate change, and recommended that he watch a broadcast of a panel discussion of the subject by scientists from our university. To my disappointment, he neither watched the broadcast nor read the material I sent him. Later in the semester we were discussing the environmental problems associated with using coal as a source of energy. I mentioned such familiar facts as mercury, sulfur dioxide, and particulate pollution that pose risks to human health. Ed complained that I was being one-sided. I thought I had been discussing only uncontroverted facts, so I asked him what I had left out. He declined to answer. The students pressed Ed to back up his complaint, until he finally revealed that his family has owned a number of coal mines over several generations. His family, he said, had provided him much reliable information that no serious harms were connected with the use of coal or other fossil fuels. It seems clear that the desire to think well of his family and the business that provided enough wealth to send him to a very expensive private college shaped his assessment of the evidence and motivated him to avoid exposing himself to information that would place his family in a bad light.

At a neighborhood party I met a new neighbor. I will call him John. During our conversation I brought up the topic of climate change. Noticing a sneer on his face, I asked him whether he was concerned about it. Significantly, his first response was that there was nothing that could be done about it anyway, unless one were willing to lower one's lifestyle, which he was not. John, who has a master's degree in engineering, stated that he worked for a group in the Air Force through which he had access to information that was not "open sourced" and which totally debunked claims about anthropogenic increases in levels of carbon dioxide as well as the connection between $\mathrm{CO}_{2}$ and climate change. Further, he claimed access to documentary evidence proving that the environmental movement was under the direction of socialists who felt it was the best hope of advancing their agenda after the collapse of communism in the Soviet Union. Over several months we exchanged memos. I summarized the case for anthropogenic causes of climate change based on some scientific papers I had read and conversations with physicists and biologists at the University of Dayton. He claimed that the research of his group clearly showed these arguments to be based on bad science. I pressed him to share that research with me, and he sent me what seemed to be a technical account using atomic absorption spectrometry to prove that it is physically impossible for increased levels of $\mathrm{CO}_{2}$ to cause climate change. I spent several weeks searching through databases of scientific journals, such as Physical Review, for any discussion 
of this position, but to no avail. Using Google, I finally found references to one article on the subject on some websites devoted to promoting skepticism about climate change - an online article by a webmaster with a degree in physics that he self-published on the website he runs for a community network. It was identical to John's write up of his "group's research." I further found that the article contained significant mathematical errors. When I confronted John about this plagiarism, he claimed to know nothing about it, and said that he was just trying to share the work of his group with me. It seems likely that his desire to maintain his current levels of consumption created unconscious biases that led to a selective analysis of the evidence. But it does not seem possible that he somehow deceived himself into believing that he and his group were the authors of the report he plagiarized. It seems much more likely that his belief in "free market" capitalism led him to feel justified in telling a conscious lie. Like Hume's religious enthusiast, "he may know his narrative to be false, and yet persevere in it, with the best intentions in the world, for the sake of promoting so holy a cause."16

Over the years, a famous radio broadcaster frequently railed against the claim that there is significant scientific agreement on climate change and its causes. So I was surprised one day to hear him admit that there was wide consensus among scientists. But, he argued, "true science" is based on skepticism, and scientists who agree with each other on climate change are not being "skeptical," so their views are ideological and not scientific. Not only had he directly contradicted his long history of claiming that there was no scientific consensus on climate, this jaw-dropping argument implies that there can never be such a thing as positive advancement of scientific knowledge. He had set up the game so that if the coin turns up tails, he wins; and if it turns up heads, his opponents lose. If there is no scientific consensus, then claims about climate change are unscientific. If there is a consensus, then it is not "true science."

Here we have three instances of people so strongly entrenched in false belief that they are able to ignore or deny contrary, authoritative evidence or engage in blatant self-contradiction. Sartre famously accounted for self-deception as a kind of bad faith in which

I must as a deceiver know the truth that is masked for me as the one deceived. Better yet, I must know that truth very precisely, in order to hide it from myself the more carefully - and this not at two different moments of temporality, which would permit us to reestablish a semblance of duality, but in the unitary structure of one and the same project. ${ }^{17}$

Self-deception, on this account, is an entirely conscious activity. In contrast,

\footnotetext{
${ }^{16}$ David Hume, Enquiries Concerning Human Understanding and Concerning the Principles of Morals, 3rd ed. (Oxford: Clarendon Press, 1975), pp. 117-18.

17 Jean Paul Sartre, Being and Nothingness, trans. Hazel Barnes (New York: Pocket Books, 1966), p. 89.
} 
George Orwell's account of double-think accounts for self-deception as a kind of mental hide-and-seek in which one learns to forget a belief, and then recall it, as the occasion demands:

To know and not to know, to be conscious of complete truthfulness while telling carefully constructed lies, to hold simultaneously two opinions which cancelled out, knowing them to be contradictory and believing in both of them, to use logic against logic, to repudiate morality while laying claim to it, . . . to forget, whatever it was necessary to forget, then to draw it back into memory again at the moment when it was needed, and then promptly to forget it again, and above all, to apply the same process to the process itself. ${ }^{18}$

Unraveling Sartre's paradoxical account would require a lengthy discussion of his metaphysics and psychology that I cannot pursue here. Likewise, Orwell's account is placed within a totalitarian context that cannot straightforwardly be applied to the cases I have been discussing. The people I have been describing do not seem to have intentionally formed false beliefs. Yet I believe that both the inaction the beliefs motivate and the beliefs themselves are blameworthy.

Some do intentionally deceive themselves. Robert Caro describes Lyndon Johnson's capacity for self-deception as one of the most powerful weapons of his political arsenal. He quotes Johnson as saying, "What convinces is conviction. You simply have to believe in the argument you are advancing: if you don't, you're as good as dead. The other person will sense that something isn't there." Caro observes that, when it was politically expedient, "Lyndon Johnson could make himself believe in an argument even if he had never believed in it before, even if he had believed in an opposite argument - and even if the argument did not accord with the facts." His associates called the process by which he achieved this conviction "revving up." One of them described it this way: "He could start talking about something and convince himself it was right, and get all worked up, all worked up and emotional, and work all day and all night, and sacrifice, and say, 'Follow me for the cause!' 'Let's do this because it's right!", "Johnson would believe it was right-no matter what he had believed before."19

A parallel case can be found in Diane Vaughan's account of how people married or living together initiate a series of events that will result in separation by justifying resentment against their partner. A primary strategy is to validate a decision to "uncouple" by finding persons within one's social circle, or even professional counselors, with whom to discuss the failings of one's partner. As a result, "the flaws in partner and relationship assume a reality they did not possess before." 20

\footnotetext{
${ }^{18}$ George Orwell, Nineteen Eighty-Four (London: Martin Secker and Warburg, 1949), p. 32.

${ }^{19}$ Robert Caro, The Years of Lyndon Johnson: Master of the Senate (New York: Vintage Books), pp. 886-87.

${ }^{20}$ Diane Vaughan, Uncoupling: Turning Points in Intimate Relationships (New York and Oxford: Oxford University Press, 1986), p. 42.
} 
When Vaughan asked her subjects whether, in retrospect, they intentionally tried to shift responsibility for the failure of the relationship to their spouses. Some admitted that they did, although others were uncertain. ${ }^{21}$

Alfred Mele has developed one of the most well-known psychological accounts of self-deception. He draws upon the Ziva Kunda's work on motivated reasoning, which she defines as "any wish, desire, or preference" which influences the formation of beliefs. One can be motivated by a desire to arrive at an accurate conclusion or to arrive at a particular, desired conclusion. Kunda shows that when the motivation is accuracy, reasoners expend more cognitive effort, attend more carefully to relevant information, and process it more deeply, often using more complex rules. Deciding how much one wants to reach an accurate conclusion is a strategic decision: the cost of the efforts must be weighed against the utility of an accurate conclusion. ${ }^{22}$

Kunda acknowledges we are not free to form a belief simply because we desire to. She proposes that sometimes the worry that $P$ might be true motivates a search for conditions under which $P$ might not be true. For example, one might search for reasons to think that an environmental study was poorly conducted, for information that some scientists dispute its findings, for past scientific predictions about environmental problems that turned out to be false, etc. One attempts to construct a rational and persuasive justification that permits one to draw a desired conclusion while maintaining an appearance of objectivity that is illusory because one does not realize that one's desires are motivating one's reasoning. One is not aware that, if one's goals were accuracy, one would not select the same information for attention, or evaluate it as one has, and one would be aware of the stronger justification for the opposite conclusion. ${ }^{23}$

Mele argues that self-deception is a type of biased belief or cognitive illusion that is motivated, but not by an intention to self-deceive. Among the sources of unmotivated biases are (1) vividness of information, which makes it more likely to be attended to (this can be a result of one's interests, how concrete the information is, its power to evoke imagery, or its proximity), (2) the tendency to focus on the objects or events most accessible to perception, memory, or imagination, (3) the confirmation bias - the tendency, when testing a hypothesis, to search more for, and more readily recognize, that which confirms rather than disconfirms one's hypothesis, and (4) the tendency to search for causal explanations, influenced by the above biases, that results in regarding relationships as causal when they are not, which in turn influences future inferences. ${ }^{24}$

While these sources of biased beliefs are simple mental tendencies not motivated by desires, Mele holds that they can be activated by our desires. The desire to

\footnotetext{
${ }^{21}$ Ibid., p. 102.

${ }^{22}$ Ziva Kunda, "The Case for Motivated Reasoning, Psychological Bulletin 108 (1990): 480-81.

${ }^{23}$ Ibid., pp. 481-82, 492.

${ }^{24}$ Alfred R. Mele, “Real Self-Deception,” Behavioral and Brain Sciences 20 (1997): 93-94.
} 
believe $P$ can increase the vivacity or prominence of data that tend to confirm $P$, influence the hypotheses one considers and so on, without the agent ever intending to deceive herself. The desire to believe $P$ can lead one to discount evidence against $P$ that would otherwise be recognized as strong, and to regard weak evidence for $P$ as stronger than it is. Desire can also activate the tendency to search for and be more sensitive to what seems to confirm $P$.

Mele supports his theory by discussing an experiment. Eighty-six male undergraduates and seventy-five women were asked to read an article claiming that women should avoid all forms of caffeine because it increases "the concentration of a substance called cAMP in the breast," which leads to fibrocystic disease "associated in its advanced stages with breast cancer." Women who heavily consumed caffeine expressed significantly lower conviction of the danger than women who consumed little or the male subjects. A plausible explanation is that females who consumed large amounts of caffeine were biased by the desire to "preserve optimism about their future health." This explanation is given further credence by another study in which the risks of caffeine were said to be fairly negligible. In that study women who heavily consumed caffeine were no less convinced that those who consumed little. ${ }^{25}$

Anna Nicholson has criticized Mele's theory. She argues that some sort of conscious intention must be involved in assessing the implications of evidence and determining which should be the focus of attention. Nicholson proposes that there is a brief period in which the agent forms an intentional plan of adopting an epistemically unwarranted belief that subsequently triggers automatic processing mental schema that facilitate the organization of knowledge and rapid interpretation of stimuli in ways that favor the belief. As the schema are repeatedly activated, they becomes stronger and more automatic. "Eventually the schema for the belief that $-P$ are chronically accessible and activated automatically in the context of any relevant cues, and in the absence of conscious acknowledgment or intention."26 Evidence is not critically evaluated on any level. The belief is primed whether evidence supports or contradicts it.

It seems to me that both types of self-deception occur. Nicholson's account seems to match Caro's description of Lyndon Johnson. But it seems implausible to claim that the women responding to the reporting on caffeine adopted a deliberate plan to deceive themselves. Under either account, moral judgments can be applied to an agent's epistemic strategies and their motives in pursuing them. Are they seeking a comforting or unchallenging answer? Are they seeking to protect cherished beliefs from scrutiny? Are they avoiding reasons for why their complacency or lack of action is blamable-reasons that would require changing the way they live or reveal such obligations as political action or donating money to environmental causes?

\footnotetext{
${ }^{25}$ Ziva Kunda, "Motivated Inference: Self-Serving Generation and Evaluation of Causal Theories," Journal of Personality and Social Psychology 53 (1987): 642-44.

${ }^{26}$ Anna Nicholson. "Cognitive Bias, Intentionality, and Self-Deception,” Teorema 26 (2007): 45-58.
} 
One cannot be blamed for wanting to be optimistic about one's health or the future prospects of humanity. But one can be blamed for not wanting to know the nature and degree of socially created risks that are avoidable. Marcia Baron notes that

... my self-deception may prevent me from ... seeing a problem or from seeing it as solvable; or I may (as in the case in which I don't face up to the fact that my son is retarded) be cruel because I insist on seeing something as it isn't. I may deceive myself in such a way that I conceal from myself the damage that I am doing to someone. In other cases my self-deceit may lead into self-delusion someone who allows my opinions to shape his, and his self-delusion may blind him to a problem that he might otherwise redress. ${ }^{27}$

Mark Johnson compares some kinds of self-deception to cowardice. ${ }^{28}$ Because of mental cowardice we avoid confronting what frightens us about the world, our responsibilities, or ourselves. It can also involve harm to others, as when one convinces oneself that a drunken friend is capable of driving safely home or that the constantly bruised child of a friend is clumsy, and not a possible victim of abuse. Self-dishonesty cannot only harm others: it often harms oneself. The harm it does to oneself can be variously articulated as undermining autonomy, creating an inauthentic self, or weakening one's agency. Baron tries to get at the nature of this harm by embracing the comparison between deceiving others and deceiving oneself:

I have suggested that deception is objectionable largely because it is manipulative, and that manipulation, in turn, is wrong because it undermines the other's agency. But don't I undermine my own agency when I deceive myself? With respect to the activities affected by my own self-induced false beliefs or pictures, I limit my own agency. I bring it about that I operate with inadequate information . . or a warped view of the circumstances. ${ }^{29}$

The primary difference is that deception of others undermines their agency all at once, as it were, whereas self-deception does so gradually and cumulatively. It can become a mental habit or strategy for avoiding unpleasant facts. Maintaining selfdeception requires the constant strain of evading or reinterpreting new evidence to prevent the prior self-deception from showing its face.

The more we dupe ourselves, the less we are able to assess evidence fairly, to be open to alternative ways of seeing things, to understand ourselves, and to be in control (insofar as this is possible) of how we live our lives. The more we dupe ourselves, the less we are able to be responsible agents. ${ }^{30}$

\footnotetext{
${ }^{27}$ Marcia Baron, "What is Wrong with Self-Deception?" in Perspectives on Self-Deception, ed. Brian McLaughlin and Amelie Oksenberg Rorty (Berkeley: University of California Press, 1988), pp. 434-35.

${ }^{28}$ Mark Johnson, "Self-Deception and the Nature of the Mind," in McLaughlin and Rorty, Perspectives on Self-Deception, p. 85.

${ }^{29}$ Baron, "What is Wrong with Self-Deception?" pp. 436-37.

${ }^{30}$ Ibid., pp. 437-38.
} 
The more one invests in believing what is contrary to the best evidence, the more impetus there is toward maintaining that belief. Simple-minded formulations that reinforce one's self-deception can become more attractive as they make it easier to avoid open-minded exploration and critical self-reflection. They make it easier to evade responsibilities that we have no right to evade, such as addressing serious social problems and alleviating suffering. ${ }^{31}$

What we care about is manifested in what we attend to and reflect upon. What we do not notice can be a result of culpable indifference toward its moral importance. Both conscious impositions of risks and failing to notice risks are reflections of a vicious moral character. A morally conscientious person thinks and feels differently than an excessively competitive, arrogant, greedy, or careless person. The same character traits and desires that produce blameworthy actions can produce blameworthy beliefs. A person can be blameworthy for the failure to do something about defects in character or unworthy desires that produce an obvious risk of failure to make the right moral choices. ${ }^{32}$

There are a number of ways in which moral judgments can be straightforwardly applied to self-deception. Blameworthy self-deception leads to immoral acts. Without a disposition to truthfulness we cannot understand what is morally required of us and act accordingly. Certainly we are morally required to exercise due diligence and concern to ensure that we are not violating moral obligations that we ourselves would acknowledge. Not to do so is moral negligence. Understanding and taking responsibility for the consequences of our action is a requirement of living a morally meaningful life. This point was dramatically brought home to me as I listened to a remarkable episode of This American Life, "Act V." The entire hour was devoted to following a group of inmates at a high security prison as they rehearsed and staged a production of the last act of Hamlet. As they assumed the roles of murderers and the murdered they came to understand the consequences and profound moral dimensions of their past crimes and to empathize with their victims. One inmate, a convicted murderer playing the ghost of Hamlet's father, described how upon first reading the lines they "jumped out" at him and made him feel things he had not felt before. He felt that the man whose life he had taken was speaking and making him realize for the first time what he had done to him. Another inmate described his performance of King Claudius's soliloquy in the chapel where he muses upon his sins, his regrets, and his inability to undo them. The actor looked upward, unaware of the audience, and it was, he said, as if that speech were his prayer to God. In listening to this episode and the transformations wrought in the inner beliefs and feelings of these violent offenders, it was palpable that they were struggling for a meaningful new life by dropping excuses, justifications, denial, and self-deception about the crimes they had committed. Perhaps it will seem

\footnotetext{
${ }^{31}$ Baron, "What is Wrong with Self-Deception?" pp. 439-40.

32 Peter Arenella, "Character, Choice and Moral Agency: The Relevance of Character to Our Moral Culpability Judgments," Social Philosophy and Policy 7 (1990): 73.
} 
outrageous to compare environmental awareness to these transformations of the inner moral lives of convicted murderers and rapists. Yet it reveals the importance of authenticity, integrity, and self-honesty to a life of moral meaning.

\section{THE ORGANIZATION OF DENIAL AND THE TRIVIALIZATION OF DESTRUCTION}

In discussing how Germans came to accept Hitler's program for the extermination of the Jews, Sabini and Silver emphasize the bureaucratization of evil. Although we are responsible for all we do, we only feel responsible for what we intend. Bureaucracies remove the sense of responsibility by instituting rules and procedures. It was these that citizens intentionally followed. Even when some action was against their inclinations, citizens could follow them unencumbered by a guilty conscience because they were only doing their jobs. In this way, evil actions can become so divorced from our intentions that even though we are responsible for bringing them about, we do not feel it. ${ }^{33}$

The ability to overcome the kinds of vices I have been discussing is often affected by our unconscious dependency upon others. Sabini and Silver discuss the problem of "moral drift" - the process whereby a group of individuals gradually cease to act on their moral commitments. To illustrate the manner in which perception is influenced by social context, they discuss an experiment in which subjects were required to pick which of three lines was the same length as a standard line. The experiment was arranged to make the determination as easy as possible. When tested alone, subjects succeeded over ninety percent of the time, but when the experiment was conducted with a group in which confederates gave the same wrong answer, over seventy-five percent of the subjects concurred with the confederates. Further, all of the subjects, and not only those who agreed with the confederates, "exhibited anxiety, doubt, and confusion" about their answers to this trivial question. ${ }^{34}$ They came to question their own powers of perception.

If such results are found in the simple comparison of line segments, how much more easily might one's moral convictions be shaken if others express open disregard for common standards of decency through either their words or actions? If we do not dissent, we make ourselves complicit in the resulting moral drift. Only if individuals make an open challenge can the tide be turned and moral clarity be introduced.

In making a moral reproach an individual's subjective, personal, inarticulate, and vague moral impressions become externalized for himself and others, and thus become a part of the social process. It is an important first step in the crystallization of the

\footnotetext{
${ }^{33}$ John Sabini and Maury Silver, Moralities of Everyday Life (Oxford: Oxford University Press, 1982), p. 66.

${ }^{34}$ Ibid, p. 47.
} 
consensual wrongness of a particular act in a particular context. . . If the making of a reproach clarifies and concretizes moral precepts, the failure to do so allows them to remain unclear both for others and for oneself. ${ }^{35}$

One might suppose that groups who engage together in hideous acts of violence either disregard the morality of their actions or have come to see them as morally acceptable. But Sabini and Silver discuss a study of delinquent gangs that found each boy in the gangs privately troubled about his behavior, but unwilling to express this openly with other members. Collectively they drifted into activities of which none of the individuals approved. ${ }^{36}$ Had some openly expressed their reservations, perhaps the moral concerns they privately held would have socially crystalized. Environmental organizations often rest their case on scientific and, increasingly, economic grounds. Perhaps the frustrating lack of progress and periodic backlash of citizens and politicians can only be overcome by open discussion of the relationship between environmental degradation and the principles by which we commonly define moral decency.

Polls of American electoral concerns usually find environmental concerns near the bottom of the list and environmental risks are rarely mentioned in political campaigns. One can speculate on why they have so little political currency. Albert Bandura notes that

People often find themselves in moral predicaments when they pursue activities that serve their self-interests but violate their moral standards by inflicting human and environmental harm. All too often, moral considerations yield to strong social forces favouring environmentally detrimental activities. People can rid themselves of the moral problem, however, by selectively disengaging their moral self-sanctions from detrimental social policies and practices. This enables them to engage in the detrimental activities with freedom from the restraint of self-censure. ${ }^{37}$

Americans might also fail to connect environmental degradation to their moral commitments because they simply regard it as the inevitable price of doing business, feel powerless to escape the demands of living and working, or believe that the institutions upon which our society is founded inevitably lead to environmental destruction. Like bureaucracies, our social and economic institutions lead us to feel no responsibilities for the evils we bring about. Drivers do not intend to degrade the environment when they fill their vehicles with gasoline, tend their grass lawns, heat their homes with electricity produced by the combustion of coal, or buy bottled water. Individually, we often have little choice. Yet collectively we are responsible.

Empirical research would be required to establish this claim, but there is reason to think that environmental issues have a low profile because Americans either do not believe that they have serious moral dimensions, or, like the members of

\footnotetext{
35 Ibid., p. 49.

${ }^{36}$ Ibid., pp. 49-51.

${ }^{37}$ Albert Bandura, "Impeding Ecological Sustainability through Selective Moral Disengagement," International Journal of Innovation and Sustainable Development 2 (2007): 10.
} 
the gangs mentioned above, they do not voice their discomfort with a society that marginalizes the health of its citizens and children, and so a social consensus around these issues never crystalizes. In this sense, we collude with each other to minimize environmental risks. In many circles neighbors, friends, and colleagues are largely silent on the subject. When someone expresses great depth of concern about environmental degradation and what it bodes for the future of humanity, the reaction is sometimes that this gloomy person has breached some unspoken rule of polite speech.

Another factor, well established by empirical research in "cultural cognition," is the influence that commitments to specific ideologies and moral systems have on perceptions of risk. The "cultural theory of risk" predicts attitudes toward risk using sets of values that form specific "worldviews." Examples of such worldviews are egalitarianism or solidarism, which regards environmental hazards with concern and favors addressing them by regulating forms of commerce that produce social inequality. Individualism, which expects persons to take care of their own needs without social assistance, is committed to free-market enterprise, opposed to government intervention, and tends to dismiss the validity of claims about environmental risks. Hierarchists embrace a social structure in which goods are distributed on the basis of such fixed characteristics as gender, class, or lineage and are skeptical about claims of approaching environmental catastrophes because they challenge the competence of the social and governing elite. ${ }^{38}$

These diverse systems of value produce the "cultural-evaluator" model of risk assessment, which emphasizes how particular visions of justice and virtue determine both what risks one is willing to impose, and what one believes to be the facts about those risks:

Guided by judgment-infused emotions and motivated by their need to preserve their fundamental ties to others, individuals naturally conform their perceptions of both the costs and benefits of such activities to the positive or negative social meanings with which those activities are imbued by cultural norms. In sum, individuals adopt stances toward risks that express their commitment to particular ways of life. ${ }^{39}$

Environmental politics becomes a symbolic conflict over what constitutes the ideal society that is little concerned with the actual facts. ${ }^{40}$ Each group strives to enact legislation to promote its own values and social status and to demean the others. One way of defusing this situation is to find ways of communicating environmental facts about risks that affirm the status of the various parties. A vast empirical literature has shown ways to decrease conflict through carefully structured procedures

\footnotetext{
${ }^{38}$ Dan Kahan et. al., "Fear of Democracy: A Cultural Evaluation of Sunstein on Risk," Harvard Law Review 119 (2006): 1070-71.

${ }^{39}$ Ibid., pp. 1087-88.

${ }^{40}$ Ibid., p. 1095.
} 
for public deliberation. ${ }^{41}$ The deliberative model is based, among other things, on the recognition that

The capacities of critical self-reflection and self-revision are not simply some individual properties that some individuals have the moral luck to possess. Their acquisition and development depend on an interpersonal process between the agent and other human beings. The ability to control one's character is a process that often requires some form of socially created transformational opportunity being made available to an individual who has the capacity to take advantage of it. ${ }^{42}$

I have elsewhere discussed ways of creating such transformational opportunities through deliberative forums, ${ }^{43}$ but I am not so naïve as to think that institutionalizing such forums can be done easily or within the foreseeable future. Such forums take money, time, and institutional support to organize, and have limited influence on the public at large. Bryan Norton has set forth a carefully developed account of how effective forums could be and, in a few cases, have been, organized to promote adaptive management. However, he seems to minimize a central problem when he writes: "Adaptive management requires no more than that a community respect science and experience as the best arbiter of differing opinions." 44 As we have seen, failure to respect or attend to the findings of science is one of the central obstacles we face. There is no silver bullet to solving the problems I have been discussing. In the meantime, those who are concerned with environmental degradations should learn to speak plainly, if diplomatically, about the moral dimensions of what our citizens believe, blameworthy inadvertence to risk, and the moral responsibility to form accurate environmental beliefs.

\section{CONCLUSION}

The myths and rhetoric of anti-environmentalism and the indifference of ordinary citizens encourage the taking of incalculable risks with the future of our planet and human welfare. It is one thing to take risks for oneself, it is quite another to risk the livelihoods, health, and future opportunities of others. In times of despair, I try to comfort myself with the thought that parents do love their children, and grandparents their grandchildren. I like to think that they would not knowingly expose them to grave risks. But they will continue to do so until they become aware of the consequences of their beliefs and the policies, or lack of policies, they encourage.

\footnotetext{
${ }^{41}$ The bibliography for this research is immense. A good starting point is the Center for Deliberative Democracy at http://cdd.stanford.edu/research.

${ }^{42}$ Peter Arenella, "Character, Choice and Moral Agency: The Relevance of Character to Our Moral Culpability Judgments," Social Philosophy and Policy 7 (1990): 82.

${ }^{43}$ Daniel C. Fouke, "Democratic Deliberation and Moral Awareness," Journal of Public Deliberation 5, no. 1 (2009): art. 10 (http://services.bepress.com/jpd/vol5/iss1/art10).

${ }^{44}$ Bryan Norton, Sustainability: A Philosophy of Adaptive Ecosystem Management (Chicago and London: University of Chicago Press, 2005), p. 430.
} 
They must be shown the connection between environmental degradation not to new values, but to what they already value the most. Creating this awareness will not be easy, but we must find ways to communicate the ethical responsibilities of citizens to inform themselves about the future that awaits us if we continue down the path of wanton disregard for our impact on the natural systems that sustain us. Confronting citizens with the conflict between their basic moral beliefs and the dangers of careless disregard for environmental issues is treacherous terrain. Outside of the controlled framework of deliberative forums environmentalists will have to be very careful how they proceed. An accusatory attitude would be counterproductive, but somehow citizens must be persuaded to critically reflect upon their most deeply held values and how they relate to the investigation and moral evaluation of risks imposed upon others. We must find ways to place political ideologies in the context of a larger set of values we share.

We can agree with "individualists" that self-sufficiency and taking responsibility for our lives is a virtue, which includes taking responsibility for detrimental effects we individually and collectively impose on others. It also includes confronting the true costs of things and how they are distributed-externalities generated by such things as how we extract and process natural resources, our modes of production, and how and where we build. Even such a firm individualist as Milton Freedman believed that there is something wrong with a system that makes others pay, through ill-health, for the products we purchase. ${ }^{45}$ We need to communicate that environmental problems - externalities or "neighborhood effects" - are problems of collective action (like building highways and bridges or protecting the safety of our food) that can only be solved by public policies. Individualists may be led to agree that some values are more fundamental than such things as "keeping government out of our lives."

We must also communicate the true value of ecosystems and the services they provide. To single out just a few of these services, consider lowly insects and their many important roles. In China's Sichuan province, pears have to be pollinated by hand because native pollinators have been decimated by lack of habitat and the application of pesticides. Avoiding such hardships requires us to understand our dependency on natural systems and the need for collective action to protect them. What such an understanding can achieve is illustrated by New York City's decision to use ecosystem services, rather than a costly engineering solution, to achieve an adequate supply of potable water. By introducing a watershed protection program for its water supply New York City avoided the \$6 billion in capital and \$300 million in annual costs that would have been required to construct and operate a new filtration plant. ${ }^{46}$

With "hierarchists" we can agree that legitimate authority and expertise ought to

\footnotetext{
${ }^{45}$ Milton Freedman, Capitalism and Freedom (Chicago: University of Chicago Press, 2002), chap. 2.

${ }^{46}$ Sandra Postel and Barton Thompson, "Watershed Protection: Capturing the Benefits of Nature's Water Supply Services,” Natural Resources Forum 29 (2005): 98-108.
} 
be respected. In the role of citizens we do have epistemic duties. But these duties cannot include achieving expert knowledge in all fields relevant to policy. To think amateurs have duties to challenge expert knowledge on ideological grounds is to be confused about our roles and intellectual obligations. No citizen has the expertise to evaluate all the scientific dimensions of our many environmental problems. Being "appropriately epistemically trusting" is a virtue for non-expert citizens when evaluating findings in the environmental sciences. ${ }^{47}$ We must take seriously the claims of scientists about the effects of such things as declining biodiversity, pollution, and climate change.

What we believe matters. Carelessly formed environmental beliefs lead to risky policies and risky inaction. Note that I have not been concerned so much with people who reject a norm, as with those who unwittingly violate a basic moral principle that they would probably accept. Over the last five years I have been conducting surveys of my students. I am sure I am not the only professor who has noted the tendency of college students to claim that there is no general agreement about morality. In teaching them how to construct moral arguments, I ask them whether they think that most Americans would agree to a series of eight moral principles that I present to them. These include such claims as, "It is wrong to impose risk on others without their knowledge or consent, especially the most vulnerable, such as children, the poor, and the elderly"; "We have a responsibility to leave the world in at least as good a shape as we have found it"; and "Depriving our children and future generations of opportunities for a good and healthy life is morally wrong." To my surprise, and to the surprise of the hundreds of students I have polled, they unanimously agree that these are core moral values to which all Americans subscribe in word, if not in deed.

I believe that animals, plants, insects, and the ecosystems they constitute impose moral obligations upon us. But so do our progeny. Parents strive to provide for their children and prepare them for future success. They need to understand the immense risks to which they expose them by their carelessly formed beliefs about, and attitudes toward, the natural world. As I said earlier, there is no global solution to these problems, but it is time to press the connection between uncontroversial moral assumptions and what we are doing to our planet. Doing so needs to be articulated individually to our neighbors, colleagues, and families, regardless of how uncomfortable the conversation. While environmental organizations should continue to emphasize the scientific basis of environmental problems and the economic benefits of addressing them, doing so is not the primary ground on which the battle might be won. Media campaigns that confront citizens with the ethical dimensions of our social actions and emphasize the obligation of living up to demands of basic human decency are, if well crafted, the more promising tool for helping us to understand what kinds of persons we are and ought to be.

\footnotetext{
${ }^{47}$ Sarah Wright, "Virtues, Social, Roles, and Contextualism," in Heather Battaly, ed., Virtue and Vice, Moral and Epistemic (Chichester: Wiley-Blackwell, 2010), p. 106.
} 